bourhood and offered bimself at $5 s$. I was also told a few days ago by a gentleman of high standing in the profession that at Woolwich medical men were charging as low as a 7s. $6 d$. midwifery fee. Thirdly, with regard to the "dignity of the mofession," I willingly withdraw or modify as far as possible any statements on this score, but I am bound to say personally that I am one of those who are not at all squeamish in charging low fees in necessitous cases, as no dignity will get blood out of a stone. Nor do I make any secret thereof, and if a person chooses to accept $10 s$. $6 d$. as a midwifery fee from one who cannot afford more I care not two straws whether it flows into his pocket through the tortuous channels of an intricate Poor-law system, or whether he takes it directly from the individual: the fee is the same, the office he performs for such fee is the same, and the dignity or indignity of accepting such fee are, to my mind, coequal, and the plea of numanity-provided this term is not used in any canting sense, as it sometimes is, to cover intrigue or to conceal invidious conditions-will suffice to protect the cloth of our profession, insomuch that such a one need not be ashamed of it and the profession in such case need not be ashamed of him.

In conclusion, Sirs, I thank you very much for your extraordinary indulgence. I would not under ordinary circumstances presume to follow suit upon the heels of a parliamentary committee. No doubt they have conducted their inquiry with ability and of course with perfect honesty of purpose, but they have had to perform their work under a most oppressive atmosphere. Their court has been literally deluged and saturated with irrelevant jargon, as the Bluebook which I possess clearly shows. Had the loquacious witnesses only been sternly repressed, asked questions and their attention demanded to the answers, but no opinion taken, and had the Committee kept their attention rivetted on the true and broad questions at issue-that is to say, in the first place, whether it is desirable to risk an excessive decrease of midwives, which, in reality, means an abrupt interference with a very complex state of society, and, in the second wlace, whether it is desirable to risk an excessive increase, and, above all, as to the practicability or, rather, utter impracticability of the whole scheme-the verdict would have Ween to my way of thinking a verdict adverse to the promoter's pretensions. I am, Sirs, yours truly,

Queen's.road, Peckham, Sept. 23rd, 1893. CLEMENT H. SERS.

\section{THE ORIGIN OF CHOLERA.}

\section{To the Editors of THE LANCET.}

SIRS, -A propos of the cases of cholera in Westminster and on board the tug-boat Eagle at Gravesend, in neither of which there appears to have been any source of infection of Asiatic cholera discovered, I would venture to make a few remarks. Are we not, in seeking to exclude cholera by elaborate and expensive precautions, rather shutting our eyes to the fact-for fact it is - that cholera or cholera germs are, and ever have been, in certain farourable localities, always with us? This applies not only to India, the supposed fons et origo of cholera and where heat and insanitary conditions are perennially favourable to its development, but also to Europe and to England; it is, in fact, everywhere endemic until circumstances render it epidemic. I do not contend that cholera cases should not be if possible excluded, or that they should not be isolated and properly treatted when they do gain an entrance, as they infallibly will; but I do say, and say emphatically, that were they excluded ever so rigoronsly cholera would nevertheless (under favourable circumstances and in spite of all external precautions) raise its hydra bead from time to time in our very midst. In certain localities the germs of cholera ever lurk unseen, but ready at any moment (under the necessary conditions of heat, moisture \&c.) to burst into life and malion activity. This is why cholera breaks out again and again in the self-same places, sparing, with apparent caprice, others in the immediate neighbourhood -even attacking sometimes only one side of a street. As certain conditions of soil, temperature, drought or rainfall are necessary for the germination and growth of plants, so are they equally needful for the existence and multiplication of certain microscopic spores and microbes. We all know how, when soil has been recently upturned, it may become rapidly covered with some luxuriant vegetable growth which has not appeared on its surface for, who can say, how cany years, but the seeds of which have lain dormant in the earth awaiting only the conditions necessary for their growth. Nothing can, to my mind, be more senseless and misleading than to make the diagnosis of cholera depend exclusively on the presence or absence of the comma bacillus in the discharges. That this bacillus is usually present in true Asiatic cholera may be readily conceded, but that it is the cause of the disease is most certainly unproven. That true cholera, whether Asiatic or sporadic, may exist without the presence of the comma bacillus no sensible observer can doubt; to deny that a case with all the characteristic symptoms of collapse, cramps, rice-water stools, cold breath and suppression of urine is cholera, simply because of the absence of the so-called distinctive bacillus is a bacteriological absurdity, which may produce the most disastrous consequences. I believe every case of autumnal diarrhoa to contain the possible germs of cholera, just as every case of sorethroat may have in it the possible germs of diphtheria; both should be considered "suspect," and both should be, during an epidemic, compulsorily notified. In this way only, by at once preventing its entrance and at the same time promptly attacking it on its very earliest appearance amongst us, can we succeed in vanquishing this dire disease.

$$
\text { I am, Sirs, yours truly, }
$$

Folkestone, Sept. 17th, 1893

$$
\text { Chas. Egerton Fitz-Gerald. }
$$

\section{MANCHESTER. (From OUR OWN CORRESPONDENT.)}

\section{Monday Evening Popular Lectures.}

DURING the ensuing winter and spring another series of popular lectures, open to the public without fee, will be given at the Owens College, the experiment, which was tried for the first time during the winter session of 1892-93, having been so successful that the college authorities have decided to repeat it this year. The lectures will be delivered on Monday evenings at 8 P. M., the first lecture being fixed for Monday, Nov. 13th, by Mr. Leslie Stephen. Amongst the lectures to be delivered during the forthcoming season I notice several of scientific interest-for example, Professor Stirling will lecture on "Respiration," Professor Weiss on "The Sensitiveness" of Plants," Professor Smithells (of the Yorkshire College) on "The Structure of Flame," and Professor Lodge (of University College, Liverpool) on "The Interstellar \&ther." If one may judge by the experience of last year, a series of intellectual treats are in store for the studiously inclined amongst the Manchester public, whilst the lecturers may, on their part, rest assured that large and appreciative audiences await them.

\section{The Ancoats Healthy Homes Society.}

On Tuesday evening last the annual meeting of the friends and supporters of the "Ancoats Healthy Homes Society" was held in the Coöperative Hall, Oldham-road. This excellent society has now been in existence four years and, according to the testimony of persons who have special opportunities of judging, its usefulness has steadily increased and its sphere has been further extended during each successive year. During last winter twenty-three meetings were held in some of the poorest neighbourhoods in Manchester, the aggregate attendance amounting to just 20,000 , and the average attendance at each meeting numbering 850. The committee of the society speak with hopefulness of the progress now being made by the city corporation in the erection of labourers' dwellings, but at the same time they think that a little more expedition might be shown in bringing the work to completion so that the people for whose benefit the dwellings were erected might have the advantage of inbabiting them before many more years have passed. The work of the committee of the society has been greatly aided by the action of the corporation in reducing to a nominal sum the cost of admission to the public baths in the district. The total expenditure of the society last year amounted to something under $£ 64$. Considering the number of entertainments given and the amount of steady and useful work done amongst the poor throughout the year, it would perhaps be difficult to find another society in England that does so much and such goo 3 work for so little money. The committee consists very largely of working men, and for this reason perhaps it is popular with the poor people who are the objects of the society's care. 